\title{
El lamento de la verdad
}

\author{
Pablo Antonio Morillo Rey \\ Centro de Estudios Teológicos - Sevilla
}

\begin{abstract}
Resumen: Es irrefutable que el hombre siempre ha mentido, algo que -sin duda- preocupa y ocupa nuestra atención. Y es éste el principal motivo que nos ha inducido a la elaboración del presente trabajo, trabajo que -tomando como puntos de apoyo, principalmente, a San Agustín y algunos documentos magisteriales- tan sólo pretende la reflexión y la reconsideración por parte del lector de tan humano"dilema": la mentira. Por otro lado, es el obispo de Hipona la figura inevitable en el contexto del cristianismo, figura que a través de dos tratados -De mendacio y Contra mendacium - nos ayudará a entender y comprender este"grave problema moral".
\end{abstract}

\begin{abstract}
It is undeniablethat human being has always told a lie, something that takes our attention and has served as purpose of this paper. Taking into account texts from St. Augustine and other Masters, we only pretend a reflection and reconsideration about such a human dilemma: the lie. In the other hand it is the Bishop from Hipona who will help us to understand this severe moral problem, by means of two books -De mendacio and Contra mendacium-.
\end{abstract}

"Magna quaestio est de mendacio" (mend. 1, 1)

\section{INTRODUCCIÓN}

Como ya bien San Agustín de Hipona (354-430) nos advirtió en la sentencia inicial ${ }^{1}$, la mentira constituye un "gran problema", bien de índole moral o incluso jurídico. Ante ello, "el gran convertido"2 siente la necesidad de mostrar a todos los cristianos católicos la ilicitud de ésta, así como las armas necesarias para poderla combatir.

\footnotetext{
1 "La mentira es un gran problema" (mend. 1,1).

2 Benedicto XVI. Audiencia General, 27 Febrero de 2008.
} 
Era, sin duda, una cuestión preocupante e inquietante el saber que muchos católicos -llevados a veces por doctrinas confusas y heréticas-aceptaban la mentira como algo totalmente lícito, creyendo que incluso las Sagradas Escrituras la refrendaban.

Así, el "heredero de Mónica"3 siente una honda preocupación acerca de la interpretación que algunos hacen del conocido texto paulino ${ }^{4}$, el cual no recoge sino la "reprensión" del apóstol de las gentes (5/10-58/67) a Pedro (i?-67) una vez llegado éste a Antioquía. De esta forma, y basándose en este pasaje, muchos podrían justificar erróneamente dicha mentira.

No obstante, y a juicio del propio obispo Africano, también se habrán de revisar otros textos bíblicos tales como: a) La teofanía de Mambré ${ }^{5}$ o b) el episodio en el cual Jacob suplanta a su hermano Esaú con el único fin de obtener la bendición paterna ${ }^{6}$.

Dichas "mentiras aparentes" -inmersas en los textos citados con anterioridad- tan sólo habrán de ser interpretadas alegóricamente, es decir, tras estas "falsas apariencias" no se esconden más que"claras certezas".

Sin embargo, para San Agustín, al cristiano no le estará permitido mentir bajo ningún concepto, pues como bien le advierte el mismo libro del Éxodo, "No dirás falso testimonio". ${ }^{7}$ Así, para él -y como ya tendremos ocasión de desarrollar- ni siquiera la mentira se podrá emplear como pretexto para salvar la vida temporal de algún hermano nuestro ${ }^{8}$.

Por tanto, ésta es algo totalmente reprobable, inaceptable y fuera de lugar en la vida de todo fiel cristiano católico, pues "la boca que miente mata el alma".

Por otro lado, también preocupa al "Padre más grande de la Iglesia latina"10, la confusión que ciertos movimientos (caso del priscilianismo) podrían imprimir en las almas de dichos fieles, de aquí que surja la necesidad -acuciante y apremiante- de redactar una obra que pueda ayudarlos en todo esto. Nacerá así el Contra mendacium, el cual analizaremos detenidamente en el apartado segundo del presente artículo.

Pero, la vigente "cuestión" no solamente captó la atención y preocupación de Padres de la Iglesia, como San Agustín allá por el siglo IV, sino que también ha continuado suscitando de igual manera dicho "interés preocupante" en la Iglesia de nuestros días. Así, buena prueba de ello no sería más que la aparición de ciertos documentos pontificios como la Evangelium Vitae (25 Marzo de 1995) o la misma Fides et Ratio (14 Septiembre de 1998), entre otros.

Éstos abordan de similar forma dicho tema. Igualmente, el Catecismo de la Iglesia Católica (1992), se convertirá en una inestimable fuente de ayuda que oriente -en torno a dicha materia- la vida de cada fiel cristiano católico.

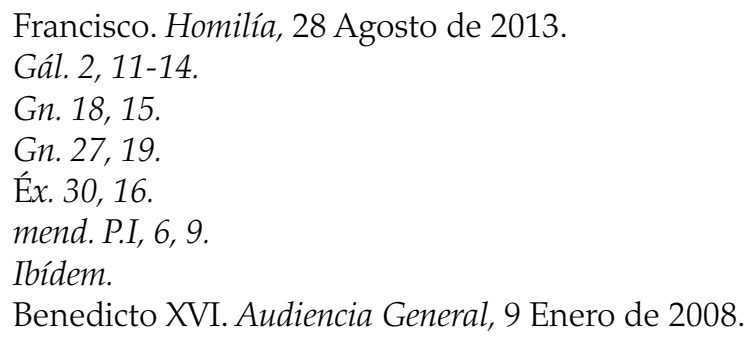


Es por todo ello, que hemos decidido emprender (llevados por la mano de San Agustín) el presente estudio, cuyos resultados presentamos a continuación:

\section{EL MAL QUE EMPAÑA LA HISTORIA}

A lo largo de la historia, la mentira ha aparecido como una constante y permanente "tentación para el hombre", eclipsándose así la verdad. De hecho, ya el neoplatónico Porfirio (232-304) señalaría que "el mentir, mucho más que reír, es lo propio del hombre"11.

Así, el ser humano -abocado por distintas circunstancias- halla en ésta una útil y segura "herramienta" ("arma") con la que poder poner a salvo su vida, ignorando así que -con dicha acción- está dando "muerte a su propia alma", a la vez que cometiendo una grave injusticia.

Pero, todo ello se agravará aún más, si el"mentiroso"12 resulta ser un cristiano, pues si tenemos en cuenta que "Dios es la Verdad"13 y la mentira -por ende- no es sino la deformación de ésta, entonces no tendremos más remedio que concluir afirmando:

\section{Mentir es hablar contra Dios ${ }^{14}$.}

De esta forma, cada fiel cristiano católico deberá rehuir de ésta, evitándola en todo momento y ocasión de su vida, pues ha de tener muy en cuenta que "Dios castigará a los que dicen mentiras injustas"15. Así, "el que desea agradar a Dios y no a los hombres no mentirá"16.

Por ello, todos aquellos que -como el apóstol Pedro- son conscientes de que "hay que obedecer a Dios antes que a los hombres"17, contemplan en dicha mentira, no sólo algo malo en sí sino, un grave mal moral:

Así, al decir que todo hombre es mentiroso es igual que decir que todo hombre es pecador, pues en ocasiones se usa la palabra mentira por la palabra pecado ${ }^{18}$.

Es el hombre, por su misma condición finita, un ser que -a veces- es incapaz de realizar lo que él mismo desea, como ya bien lamentaba el Apóstol al exclamar que "no hago el bien que deseo, sino el mal que no quiero"19. De esta manera,

\footnotetext{
11 Alexandre Koyré. "La función política de la mentira moderna", en Revista de la Asociación Española de Neuropsiquiatría, Vol. 17, nº 63, 1997, 501-514.

12 "A los que mienten por mentir se les ha de llamar mentirosos" (mend. P. I, 11, 18).

13 Trin. VIII, 2, 3.

14 c. mend. $4,7$.

15 c. mend. 1, 1.

16 mend. P. II, 18, 37.

17 Hch. 4, 19.

18 c. mend. $20,40$.

19 Rom. 7, 19.
} 
será éste idéntico "pesimismo" el que empañará todo el amplio y complejo sistema antropológico agustiniano, puesto que dicho mal será precisamente el que hará de él un"ser miserable"20.

De igual forma, el Concilio ecuménicoVaticano II (1962-1965) también se hará eco de todo esto en la constitución Gaudium et spes (7 Diciembre de 1965) ${ }^{21}$.

No obstante, y como bien se nos advierte en el libro del Deuteronomio ${ }^{22}$, también el ser humano -haciendo gala de su libre albedrío- es capaz de hacer el bien, recordándonos así que es "la imagen de Dios (imago Dei), en cuanto que es capaz de Dios y puede participar de Dios"23.

Así, para todo cristiano, será "la ley inscrita por Dios en el corazón humano, en su conciencia, que le ayude o aconseje evitar el mal y hacer el bien"24, ya que él "tiende hacia el bien, pero es también capaz del mal"25.

Sin embargo, ambos "principios" (bien y mal) conviven diariamente, como bien nos muestra la parábola evangélica de la cizaña ${ }^{26}$.

Todo ello, no pretende significar -como ya advierte San Agustín- la no existencia de oposición alguna entre verdad (representada por el bien) y mentira (representada por el mal), pues:

Como la luz y las tinieblas, la impiedad y la piedad, la bondad y la iniquidad, el pecado y la obra buena, la salud y la enfermedad, la vida y la muerte, así son totalmente opuestas entre sí la verdad y la mentira ${ }^{27}$.

Por todo lo cual, y como ya bien apuntaba el Estagirita (384-322 a. C), "la mentira en sí es reprensible y mala, y la verdad, por lo contrario, es bella y digna de alabanza"28.

Mientras aquélla, con su "oscuridad", intenta deformar el "rostro" de ésta, ésta (la verdad) con su"esplendor", ilumina y guía los pasos de todo hombre por el camino-peregrinaje de esta vida.

El cristiano, según el "gran enamorado de Dios"29, debe ser consciente de todo esto, pues -bajo ningún concepto o pretexto- hará uso de la mentira, ya que "los hijos de la Jerusalén celestial, que son hijos de la verdad, no deben mentir"30, puesto que cuanto más ame la verdad, tanto más debe odiar la mentira ${ }^{31}$.

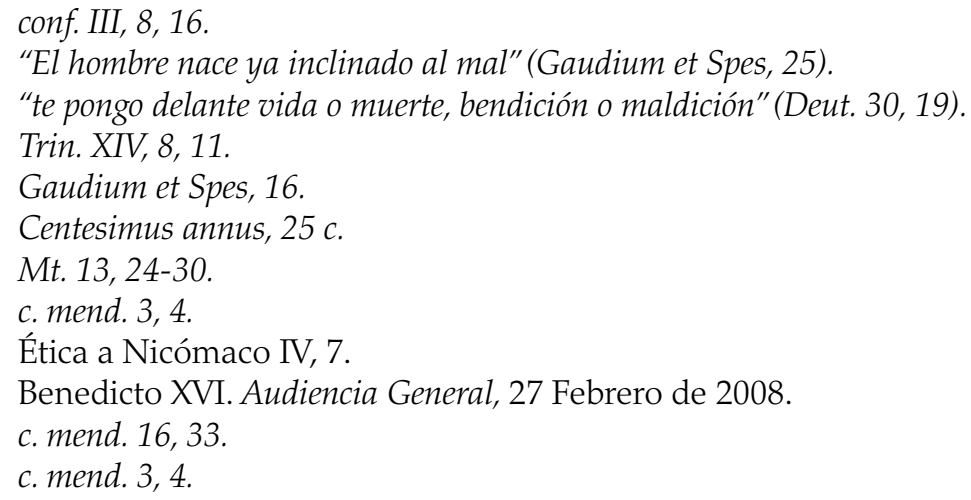


Por tanto, y aunque desafortunadamente ésta abunda en la vida ${ }^{32}$-prevaleciendo en el momento actual- siempre habrá de ser rehusada, reprobada por todos, aunque -y como ya se ha dicho anteriormente- especialmente por todo fiel cristiano.

Es la mentira, o incluso la retórica ("el arte de mentir) ${ }^{33}$, una especie de "fenómeno sociológico" del que nuestros tiempos podrían dar "buena cuenta", pues -como bien subrayará Alexandre Koyré (1892-1964)-:

nunca se ha mentido tanto como en nuestros días ${ }^{34}$.

Sin embargo, el hombre puede sentir diversas motivaciones que le animen a ello: ansia de poder o incluso la obtención de placer ("mentir por mentir"). Es en este último sentido que el cristiano deberá estar alerta, fundamentalmente para poder "rechazar toda mentira que dañe injustamente a alguien: A nadie se debe inferir injuria alguna, por leve que sea"35.

No obstante, el ser humano se muestra incapaz de mantenerse en la veracidad, de ser veraz, por lo que -cual "animal salvaje"36 - tan sólo se limita a responder instintivamente a los demás.

Por otro lado, hemos de tener siempre muy en cuenta que la verdad supone "la castidad del alma"137, la pureza de nuestro"hombre interior", mientras que "toda mentira es mala"38 ya que encubre, enmascara un pecado, "blasfemias y perjurios"39.

Y será este último aspecto que deberá ser siempre evitado, pues el hombre no puede ni debe acostumbrarse a hacer de aquélla, la mentira, su contexto vital, pues "la costumbre de mentir no conduce a nada bueno"40.

Sin embargo, existe una clase de hombres que no pueden evitar mentir, ya que su "placer" reside únicamente en ello: Son los denominados -en lenguaje agustiniano-"mendaces" ${ }^{\prime \prime 1}$. Como claro ejemplo podríamos citar a los priscilianis$\operatorname{tas}^{42}$, para quienes la mentira llegará a convertirse en una especie de "dogma"43 -lo cual deberá ser duramente combatido-.

Así, será éste el principal motivo que induzca al "genio de Europa"44 a componer una obra que constituya un fuerte y eficaz instrumento defensivo contra

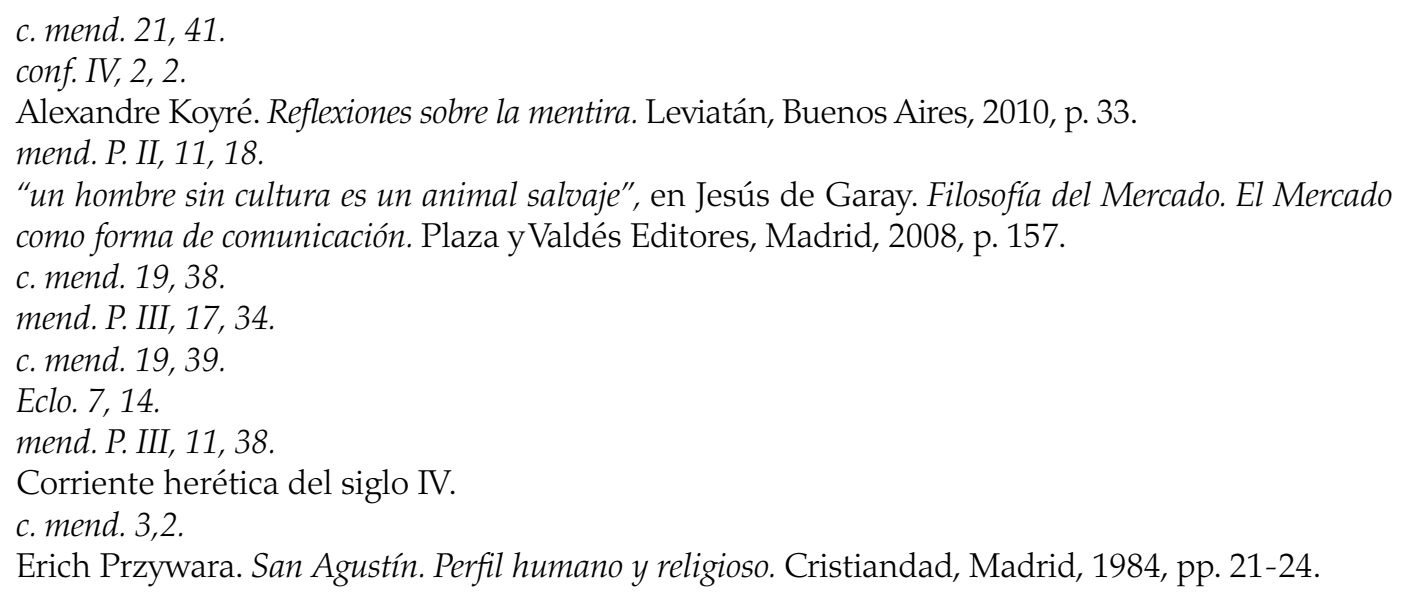


los ataques de dicho movimiento herético. De esta forma, será dicho tratado -junto a otro de idéntica temática- el objeto de análisis del siguiente apartado.

\section{AUGUSTINUS ET DE MENDACIO: CONTRA MENDACIUM}

Sin duda, es evidente que para "el primer hombre moderno"45 la cuestión de la mentira -y sobre todo el hecho de mentir- constituye un "problema crucial" para su sistema filosófico-antropológico, puesto que ésta contribuye a"engrosar"su mal personal. Por todo ello, se hará necesario e imprescindible ayudarlo. Y justamente a ello responderá San Agustín con la publicación de dos obras: De mendacio (395) y Contra mendacium (420/422).

\subsection{De mendacio}

También escribí un libro sobre "La mentira", el cual, aunque se entiende con alguna dificultad, sin embargo es útil para ejercitar el ingenio y la inteligencia, y aprovecha aún más para amar la veracidad en las costumbres ${ }^{46}$.

Con estas palabras, recogidas en el libro de las Revisiones $(\approx 427)$, el genio de Hipona alude a la autoría de dicho tratado, tratado que -aunque deseó retirarlo del "mercado" y reemplazarlo por otro como el Contra mendacium- se integra indiscutiblemente en la vasta producción agustiniana (el Indículo de San Posidio (¿?-437), catalogador de las obras de San Agustín, lo omite).

Por la datación del opúsculo (principios del año 395), podemos afirmar que se trata de la última obra redactada antes de su consagración episcopal, acaecida en el año 396, como titular de la sede de Hipona (actual Annaba, en Argelia).

Según parece, el origen del presente tratado se halla en una "pequeña discusión" entablada entre el autor de Confesiones (397-398) y el"ermitaño de Belén", tal y como aparece reflejada en el epistolario de aquél ${ }^{47}$.

El motivo de dicha"disputa" es claro: una interpretación que San Jerónimo (340-420) realizara sobre la controversia acaecida entre los apóstoles Pedro y Pablo $^{48}$, interpretación que -según San Agustín- puede infundir en los fieles cristianos la idea de la permisión de la mentira por parte de las Escrituras Santas:

He leído asimismo ciertos escritos que se dicen tuyos sobre las cartas de San Pablo. Al exponer la carta a los Gálatas, llegas a tocar aquel pasaje en que San Pedro es disuadido de su pernicioso disimulo. Y lamento, hermano, no poco que te hayas arrogado la protección de la mentira, si eres tú y no otro quien redactó este escrito ${ }^{49}$.

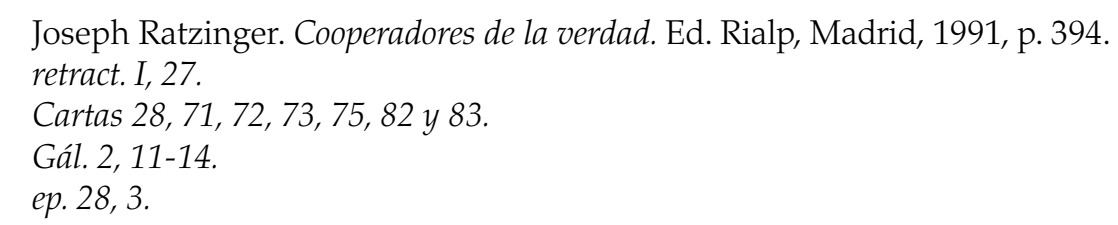


A todo ello Jerónimo responderá con las siguientes palabras:

Preguntas en segundo lugar por qué en los comentarios a la Epistola a los Gálatas he dicho que Pablo no pudo reprender en Pedro lo que él mismo ejecutaba, ni podía combatir en otro la misma simulación de que él era reo. Afirmas que la reprensión apostólica no la exigía la práctica del ministerio, sino que fue una verdadera reprensión.

Anuncias que yo no debo enseñar la mentira, sino que todas las cosas que están escritas han de sonar tales cuales están escritas... Por el contrario, me parece que yo soy más tímido y cauto, pues sintiendo la debilidad de mis fuerzas, he seguido los "Comentarios" de Orígenes. Escribió él sobre la Carta a los Gálatas cinco volúmenes... 50.

Así, ante tal "disputa epistolar", San Agustín siente la acuciante necesidad de llevar a cabo una laboriosa y amplia investigación, investigación que -igualmente- conducirá a descubrir ciertos autores también defensores de este erróneo punto de vista: Clemente de Alejandría (130-216/17); Orígenes (185-254); Hilario de Poitiers (315-367); Sulpicio Severo (363-425) o el mismo Juan Crisóstomo (347-407).

No obstante, lo que ha de quedar suficientemente claro y asentado, lejos de toda controversia, es que la verdad quedará simbolizada en Dios y, por ende, la mentira no supondrá sino el pecar contra Él mismo, punto de vista compartido y adoptado por Santo Tomás de Aquino (1224/25-1274) en sus escritos ${ }^{51}$.

Por otra parte, y en cuanto a la estructura del tratado en sí, dos partes fundamentales vertebrarán el De mendacio: una primera que abarcará desde el capítulo primero al décimo, y otra segunda que comprenderá desde el undécimo al vigésimo primero. Mientras que en aquél presenta tanto la naturaleza como la"malicia" de la mentira, en ésta nos ofrecerá una amplia clasificación y análisis de las diversas tipologías de mentiras existentes.

Pero, ¿qué es el mentir para el maestro de Tagaste? ¿En qué consiste? Pues mentir, sencillamente, no será más que tener una cosa en la mente y expresar otra muy distinta a través de palabras o signos ${ }^{52}$, es decir, la boca no habla lo que la razón expresa. Sin embargo, hemos de tener muy en cuenta que no toda aquella persona que diga algo falso está mintiendo, puesto que cree u opina que es verdad lo que está diciendo.

Sería este el caso de los denominados rudes ${ }^{53}$, de aquellas "personas buenas y benévolas que no intentan dañar a nadie" ${ }^{\prime \prime 54}$, no así de todos aquellos que "mienten por mentir" ("mentirosos compulsivos", podríamos llamarlos). Su mayor pecado se encontrará en su deseo de engañar intencionadamente, algo que lo distinguirá perfectamente del bromista:

Las bromas no son mentiras, pues el que las hace no tiene intención de engañar ${ }^{55}$.

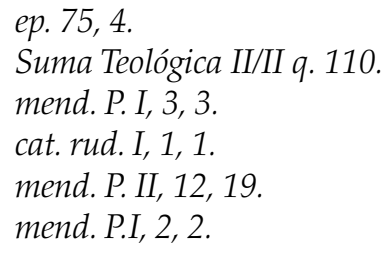


El engaño, la mentira, no tendrá cabida alguna en todo aquello que sea materia de religión ${ }^{56}$, algo que -sin duda- quedará refrendado por las Escrituras ${ }^{57}$, pues:

No dirás falso testimonio ${ }^{58}$; la boca que miente mata el alma ${ }^{59}$; Destruirás a todos los que dicen mentira ${ }^{60}$; Sea en tu boca sí, sí o no, no ${ }^{61}$ o Por lo cual, renunciando a toda mentira, habla la verdad ${ }^{62}$.

No obstante, hay quienes -sin pudor alguno- harán todo lo contrario, es decir, emplearán los textos bíblicos para apoyar la licitud del engaño, pues "Sara, después de reírse niega a los ángeles que lo hubiese hecho"63; "Jacob responde a su padre que era Esaú" "64; "las comadronas egipcias mienten, con la aprobación y el favor de Dios, para salvar de la muerte a los niños hebreos recién nacidos" ${ }^{\prime \prime}$.

Sin embargo, lo que no deja cabida a duda alguna es que toda mentira-causa de pérdida de la vida eterna- sea idéntica la una a la otra. Para ello, San Agustín nos ofrecerá el siguiente "cuadro clasificatorio"66.

1. La mentira capital es aquella que se basa, como ya hemos señalado anteriormente, en materia religiosa, mentira a la que nadie deberá ser"arrastrado".

2. Aquella (mentira) que daña a alguno pero que, sin embargo, no aprovecha a nadie.

3. El engaño favorece a alguno, perjudicando seriamente al otro.

4. Es la mentira producida por el mero y simple hecho de alcanzar placer a través del mentir o engañar: Es la mentira"pura y simple".

5. Pretende agradar en el transcurso de "conversaciones dulces".

6. A nadie perjudica, pero a alguno le aprovecha.

7. A nadie perjudica, y aprovecha a alguno (sería el caso de no delatar o entregar al hombre que buscan o persiguen para matar).

8. A nadie perjudica, siendo útil para evitar que alguien sea mancillado en su cuerpo.

Pues bien, entre estas ocho clases o tipos, las cinco primeras han de ser evitadas y rechazadas por todos en todo momento u ocasión, mientras que la sexta y séptima lo serán -fundamentalmente- por los "auténticos fieles y personas

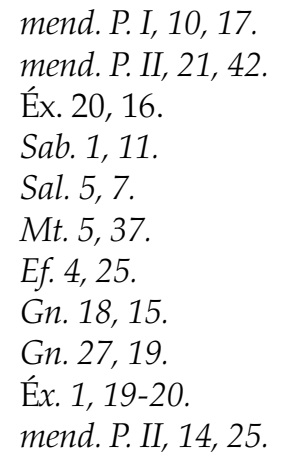


virtuosas" ("se ha de destruir el dogma priscilianista de que las personas piadosas deben mentir para ocultar sus sentimientos religiosos"67). Por último, la octava"no se podrá hacer de ningún modo".

Pero, también hay otro tipo de mentira que no podría ser perdonada a ninguna persona y que se dará cuando -además de mentir- se rehúse el confesar los pecados, "pretendiendo así una falsa santidad y no confesando sus pecados en la penitencia"68.

Dicha santidad, tan sólo se obtendrá cuando se observe y conserve estos "tres tesoros": "el poder del cuerpo, la limpieza del alma y la verdad de la doctrina"69, la cual no es otra sino la cristiana ${ }^{70}$.

Así, y en cuanto a lo segundo, el alma guardará siempre su castidad, su limpieza, cuando el amor sea en ésta ordenado y nunca someta "lo superior a lo inferior" Así mismo, es también aquí, en el alma, donde reside la pureza del cuerpo ${ }^{72}$.

En definitiva, la mentira es algo que -en su integridad-debe ser rechazada, ya que constituye un "pecado"73, pues lo contrario no supondría más que aumentar la ceguera del hombre, caso de los priscilianistas. Y será justamente la lucha contra esta doctrina el principal objetivo del Contra mendacium.

\subsection{Contra mendacium}

Después, como escribí otro libro con el título "Contra la mentira", decidí, aún mandé que con más razón aquél (La mentira) se destruyese, pero no se hizo... Sin embargo, los dos persiguen el mismo fin $^{74}$.

Nuevamente nos hallamos ante otro nuevo tratado agustiniano, cuya autoría queda suficientemente refrendada. Tal es así, que el mismo obispo de Hipona subrayará que no se trata sino de una "gran mejora con respecto al anterior de "La mentira"'"75, puesto que en éste se podrán encontrar datos que el otro obviará, y viceversa. Por lo tanto, ambas obras se complementarán mutuamente.

De esta forma, y a diferencia del susodicho de La mentira, dicho tratado sí será recogido por el Indiculo de su biógrafo San Posidio de Cálama ${ }^{76}$.

En cuanto a su datación, parece situarse probablemente entre los años 420 y 422, por lo que su autor ocuparía ya la sede episcopal de Hipona (en el año 396, como ya se apuntó anteriormente, fue nombrado obispo auxiliar y un año más tarde titular).

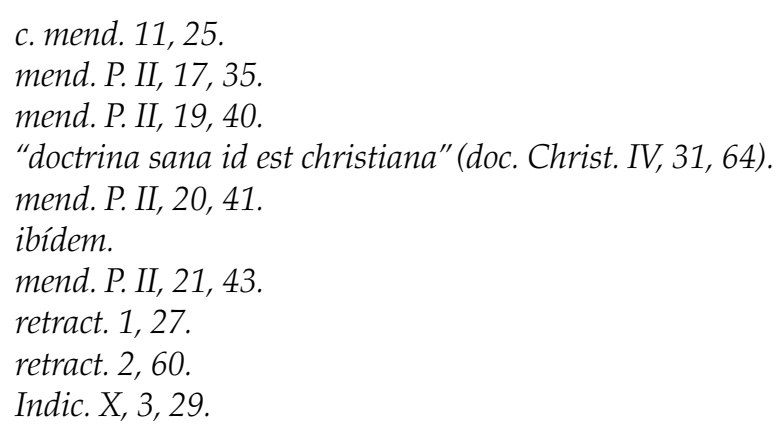


El principal motivo de este libro no será otro sino el ayudar a todos los fieles cristianos católicos en la lucha priscilianista, movimiento herético del siglo IV. Así, la obra es dedicada a Consencio (principios sigloV), sacerdote español que se hallaba muy involucrado en la lucha anti-priscilianista y al que invita viajar a Hipona para -además de visitarlo- poder"intercambiar ideas":

Te he rogado que vinieras aquí, porque me ha complacido el ingenio que muestras en tus libros ${ }^{77}$.

Es Prisciliano de Ávila (345-385) un obispo hispano que da lugar al nacimiento de una herejía cristiana, la cual seguirá "dogmas entremezclados de los gnósticos y maniqueos... Sobre Cristo aceptan la secta de Sabelio, diciendo que él mismo es a la vez no solo el Hijo, sino también el Padre y el Espiritu Santo"78.

Su“consigna" o señal de identidad quedaría reflejada en una sencilla y simple frase como es el "jura, perjura, pero no descubras el secreto" creían erróneamente algunos católicos:

Por entonces escribí el libro "Contra la mentira", cuyo motivo fue que a algunos católicos les pareció que debían simular que ellos eran priscilianistas para poder penetrar en sus guaridas, para rastrear a los herejes priscilianistas, que estimaban debían ocultar su herejía no sólo negando y mintiendo, sino también perjurando. Para prohibir que se hiciera eso, compuse ese libro ${ }^{80}$.

Para el genio de Tagaste, éstos resultan ser aún peores que los citados maniqueos, puesto que "no rechazan nada de las Escrituras canónicas, que leen todos juntamente con los apócrifos, y los citan con autoridad"81, por lo que -bajo unas Escrituras adulteradas y "alegorizadas según su capricho"82 - persuaden "a las personas piadosas a ocultar sus sentimientos religiosos con la mentira"83.

No obstante, y como se dijera anteriormente, todos los hijos de la"Ciudad de Dios" han de evitarla, para lo cual -y a través de veintiún capítulos- San Agustín les dará las claves.

En primer lugar, hemos de admitir que la mentira o engaño no resulta útil bajo ningún concepto, ya que puede conducir incluso hasta la propia "muerte del alma":

$Y$, así, mientras pretendemos enseñar la fe por medio de la mentira, conseguimos, justamente, que nadie tenga fe en nadie ${ }^{84}$.

ep. 120,1 .

Haer. 70, 1-2.

Ibidem.

retract. 2, 60 .

Haer. 70, 1-2.

Ibidem.

c. mend. 11, 25.

c. mend. $4,7$. 
Por tanto, hemos de odiarla y evitarla en todo momento, combatiéndola y "desenmascarándola" con la verdad. Sin embargo, esta última deberá salir, brotar del corazón, pues de lo contrario"no servirá de nada":

...puede suceder que alguien diga con la boca la verdad y no le sirva de nada, porque no la siente de corazón, pues él mismo no cree lo que dice ${ }^{85}$.

Por otra parte, la mentira (que para él equivale a pecado) si se comete con buena intención no revestiría la gravedad de aquella que sí se comete con la única finalidad de dañar o injuriar, pues "más grave es el pecado que se comete con la intención de dañar que el que se hace con la intención de ayudar"86, ya que "son más leves los que se han cometido con buena intención" ${ }^{\prime \prime 7}$.

A veces, es nuestra misma humanidad la que nos conduce a pecar ${ }^{88}$, nos conlleva mentir. Pero, lejos de toda justificación, hemos de pedir perdón "confesándola y haciendo penitencia" ${ }^{\prime \prime 29}$.

En definitiva, el principal objetivo agustiniano en esta obra será hacer ver al cristiano católico que, frente a lo afirmado por la herejía priscilianista, la mentira siempre ha de ser rechazada y duramente combatida, teniendo muy en cuenta que "aunque todo el que miente quiere ocultar la verdad, sin embargo no todo el que quiere ocultar la verdad miente, ya que muchas veces ocultamos la verdad, no al mentir, sino al callar"90, pues a veces dichas mentiras no son tales, solamente están en un "lenguaje figurado, metafórico" ${ }^{\prime 1}$, caso de ciertos pasajes relacionados con personajes bíblicos como Abraham o el mismo Jacob.

Al mismo tiempo, les advierte sobre la peligrosa posibilidad de que ésta se transforme en"blasfemia", puesto que "cuando se blasfema se dicen cosas falsas del mismo Dios"

Por último, "el Padre común de la Europa cristiana"93 concluye este tratado con un esperanzador anhelo: vernos libre de toda mentira (pecado) cuando, al llegar a la Ciudad Santa, solamente vivamos de la gracia divina ${ }^{94}$, ya que:

Nuestro destino final no está en este mundo, sino en la Ciudad de Dios, pues allí descansaremos y contemplaremos, contemplaremos y amaremos, amaremos y alabaremos ${ }^{95}$.

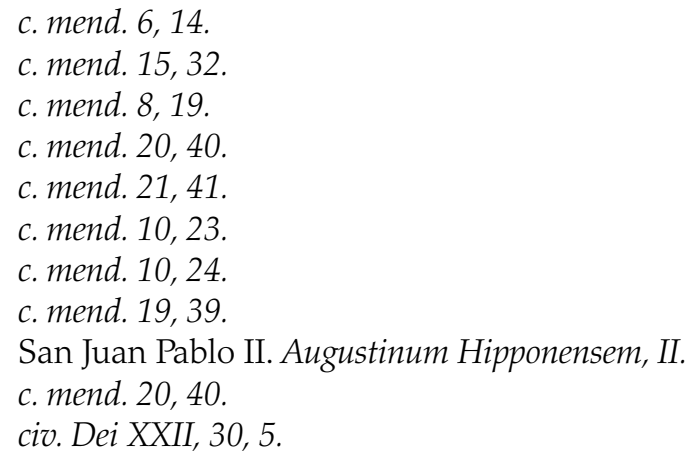




\section{REFLEXIONES MAGISTERIALES}

Una de las tareas principales de todo cristiano es la de "hacer resplandecer la Palabra de verdad" ${ }^{\prime \prime 9}$. Si tenemos en cuenta que esa Verdad -y como ya apuntamos con anterioridad- no es sino Dios mismo, y que la mentira -según nos indicó el mismo San Agustín- no consistía sino en hablar contra Él, entonces podemos deducir con suficiente claridad que la misión de dicho cristiano no será otra que la de exaltar y hacer brillar la Palabra de Dios en medio de las"tinieblas", de la confusión y el caos.

De esta forma, la Iglesia -a través de su magisterio- también desea (siguiendo las huellas del Doctor de la Gracia) ayudar a los fieles en esta "tarea". Así, hallamos ciertos documentos como:

Tres son las grandes encíclicas sociales del magisterio de San Juan Pablo II (1978-2005): Laborem exercens (14 Septiembre de 1981)/ Sollicitudo rei socialis (30 Diciembre de 1987) y Centesimus annus (1 Mayo de 1991), objeto esta última de análisis.

Así, con esta última el Papa santo conmemoraría el centenario de otra gran encíclica social como la Rerum novarum (15 Mayo de 1891), del Pontífice León XIII (1878-1903).

Pero, en la encíclica que nos ocupa, la mentira no es presentada sino como aquella que es útil para justificar, avalar todo tipo de acto violento:

...la violencia tiene siempre necesidad de justificarse con la mentira...97,

pues es ésta (bien la violencia, bien la mentira) como una especie de vehículo que -a veces- el hombre puede emplear para llevar a cabo el proyecto, o los proyectos, de que él cree estar en posesión ${ }^{98}$.

Un claro ejemplo de todo ello, se encontraría plasmado en el célebre episodio acaecido entre Caín y Abel ${ }^{99}$, como bien recogerá la encíclica Evangelium vitae:

Con la mentira Caín trata de ocultar su delito. Así ha sucedido con frecuencia y sigue sucediendo cuando las ideologías más diversas sirven para justificar y encubrir los atentados más atroces contra la persona ${ }^{100}$.

Así, nuevamente la mentira continúa -aún en nuestros tiempos modernos y tecnológicos- justificando y ocultando todo tipo de violencia, agresiones, muertes o asesinatos cometidos contra nuestros hermanos, aconteciendo de igual manera y cobrando realidad reiteradamente ese pasaje veterotestamentario,

\footnotetext{
Benedicto XVI. Porta fidei, 6.

Centesimus annus, $23 \mathrm{c}$.

Centesimus annus, $25 c$.

Gn. 4, 9.

Evangelium vitae, $8 e$.
} 
"una página que cada día se vuelve a escribir, sin tregua y con degradante repetición en el libro de la historia de los pueblos"101.

De esta forma, en dicho pasaje bíblico no se muestra sino "la codicia y la ira en el corazón del hombre, por la cual se convierte-muchas veces-en el mayor enemigo de sus semejantes" ${ }^{\prime 102}$.

No obstante, el hombre no se encuentra predestinado al mal ${ }^{103}$, a la mentira, al engaño, por lo que su disposición es siempre la de hallar la verdad, hallar el bien, como nos indica la encíclica Fides et ratio:

Pero, a pesar de esto, incluso cuando la evita (la verdad), siempre es la verdad la que influencia su existencia; en efecto, él nunca podría fundar la propia vida sobre la duda, la incertidumbre o la mentira; tal existencia estaría continuamente amenazada por el miedo y la angustia. Se puede definir, pues, al hombre como aquel que busca la verdad ${ }^{104}$.

Pero, los creyentes - como bien nos advirtiese San Agustín- no deberán mentir, huyendo siempre de esta tentación ${ }^{105}$, por lo que el mundo actual necesitará más que nunca y urgentemente un testimonio creíble $\mathrm{e}^{106}$, un testimonio capaz de convencer:

...esperemos que el testimonio de vida de los creyentes sea cada vez más creíble ${ }^{107}$.

Y será justamente este motivo, el testimonio de la fe y la conversión del corazón, lo que animó al Papa emérito Benedicto XVI (2005-2013) a convocar un Annus fidei (11 Octubre de 2012 - 24 Noviembre de 2013):

"el Año de la fe es una invitación a una auténtica y renovada conversión al Señor"108, pues -como ya bien apuntaba en su Carta apostólica en forma de "Motu Proprio"Porta fidei (11 Octubre de 2011) - muchas veces ésta (la fe) se ve relegada e incluso en ocasiones negada en nuestras propias vidas de creyentes. Un claro resultado de todo esto, serían los popularmente denominados por la misma sociedad "cristianos vergonzantes", puesto que:

sucede hoy con frecuencia que los cristianos se preocupan mucho por las consecuencias sociales, culturales y políticas de su compromiso, al mismo que siguen considerando la fe como un presupuesto obvio de la vida común. De hecho, este presupuesto no sólo aparece como tal, sino que incluso con frecuencia es negado ${ }^{109}$.

\footnotetext{
101 Evangelium vitae, $7 c$.

102 CIC, 2259.

103 Evangelium vitae, $8 a$.

104 Fides et ratio, 28.

105 c. mend. 16, 33.

106 Porta fidei, 15.

107 Porta fidei, 9.

108 Porta fidei, 6.

109 Porta fidei, 2.
} 
Así, cuando aquélla falta en nuestras vidas todo se vuelve oscuridad, todo se ve empañado y envuelto en el"reino de la mentira", pues nunca habita en el mundo de las tinieblas, ya que es "luz"110.

No sin razón, el propio San Agustín denomina a la noche "la madre de los malvados"111, puesto que las tinieblas no representan más que "las mentes de los hombres, cegadas por los deseos depravados y la infidelidad"112.

Por otro lado, el Papa Francisco (2013) en su primera encíclica Lumen fidei (29 Junio de 2013) ${ }^{113}$ cree que cuando la luz (que no simboliza otra cosa sino la fe) nos falta, entonces todo se vuelve repentinamente confuso, siendo así imposible distinguir el bien del mal114. De igual forma, dicha luz también implica la verdad, una verdad que -como el mismo Pontífice apunta- "ya no interesa" ${ }^{\prime \prime 15}$.

Actualmente, nos encontramos ante un mundo "carente de verdad"116, un mundo en el que es urgente y necesario recuperar la conexión entre la fe y la verdad, una verdad que -lejos del tedio de lo falso- necesita del amor.

Es así como aquélla no se convertirá en algo frío, impersonal, capaz de oprimir la vida concreta de cada individuo ${ }^{117}$.

Por todo ello, la existencia de la mentira en las relaciones interpersonales, no puede suponer sino discordia, desconfianza y distanciamiento entre los mismos seres humanos, como bien nos recuerda el Catecismo de la Iglesia Católica:

La mentira es funesta para toda la sociedad: socava la confianza entre los hombres y rompe el tejido de las relaciones sociales ${ }^{118}$.

Es el hecho de mentir como una "gran piedra", un obstáculo que separa y desune, haciendo a la vez difícil la convivencia entre semejantes, entre hermanos -ya que nuestro parentesco no es sino espiritual, pues éste nos agrupa "en una única gran familia donde todos participamos del mismo bien fundamental: la idéntica dignidad personal"119-.

Por tanto, dicha mentira no es más que el resultado de la soberbia humana, de la "madre de la envidia"120, de aquella "falsa grandeza de los débiles"121 que es

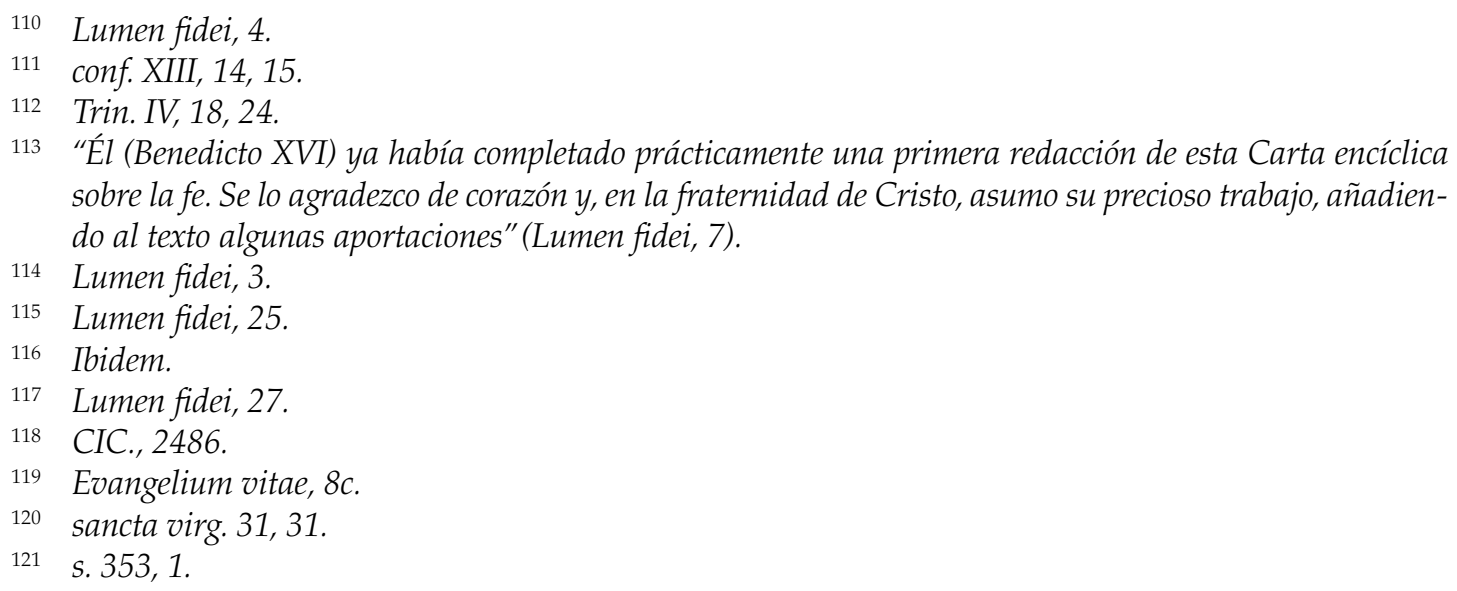


capaz incluso de hacer que el hombre olvide a su propio hermano, que olvide íntegramente el sentido de responsabilidad para con sus semejantes. Claros síntomas de todo lo dicho serían, según San Juan Pablo II:

la falta de solidaridad con los miembros más débiles de la sociedad -es decir, ancianos, enfermos, inmigrantes y niños-y la indiferencia que con frecuencia se observa en la relación entre los pueblos, incluso cuando están en juego valores fundamentales como la supervivencia, la libertad y la paz ${ }^{122}$.

Sin embargo, el hombre -aunque desea mentir- no quiere en cambio ser engañado bajo ningún concepto, algo que tan sólo acontecerá de una manera plena en la vida eterna, pues "En la vida eterna, nadie engaña y nadie es engañado.....Se encuentran muchos que quieren engañar, pero ninguno (nadie) que quiera ser engañado"123, pues sólo "Él no puede engañar ni ser engañado"124.

Pero, la mentira -a veces- no sólo aparece como un "gran problema" en la vida del hombre, sino también -y ante todo- como un profundo y hondo"dilema opresor" en su alma. Así, ¿podríamos considerarla acaso como un problema moral?

\section{LA MENTIRA, ¿PROBLEMA MORAL?}

Todo hombre malvado lo es para consigo mismo, siendo su propio verdugo. Él mismo es su castigo, porque lo atormenta su conciencia ${ }^{125}$.

Es así, que -en muchas ocasiones- la mentira angustia y aflige la conciencia del propio hombre, de aquel que ha engañado libremente a su semejante con el único y exclusivo fin de"dañarlo". De esta forma, aquélla pasa a convertirse en un"gran y grave problema moral", adquiriendo de forma inmediata la dimensión de "pecado".

Ya, si recordamos, el mismo obispo hiponense nos advirtió que se podría intercambiar la palabra mentira por la palabra pecado ${ }^{126}$, puesto que ésta no consistía sino en hablar contra el mismo Dios ${ }^{127}$.

De esta manera, el "estrago" que causa y suscita el pecado en el hombre -podríamos decir- es similar al provocado por la mentira: alejamiento y ruptura con Dios, deseando aquél hacer sólo su propio capricho:

Porque no vivir conforme a la verdad de Dios y sus derechos, sino según el capricho del hombre, eso es la mentira ${ }^{128}$.

\footnotetext{
122 Evangelium vitae, $8 e$.

123 s. $306,8-9$.

124 s. $330,1-3$.

125 en. Ps. 36.

126 c. mend. 20, 40.

127 c. mend. 4, 7.

128 doc. Christ. XIV, 4, 1.
} 
El ser humano, arrastrado por el "padre de la mentira" (Jn. 8, 44) ${ }^{129}$, tan sólo desea otorgar satisfacción a su propio ego, empleando -si fuera preciso- cualquier "arma" para defenderse. Por ello, el más débil e inferior contemplará en dicha mentira su "arma preferida" con la que poder combatir a su adversario, afirmarse y, al mismo tiempo, vengarse de él.

Resulta algo irrebatible, que el hombre -a lo largo de su prolongada historia- siempre ha empleado el engaño, lo falso, puesto que para él no será tarea fácil el mantenerse, decir y escuchar la verdad, ya que no siempre la busca o la desea.

Sin embargo, nunca se ha llegado a mentir de una manera tan constante y sistemática como en los momentos actuales. Esto podría deberse, probablemente, a distintos factores como: diversos ámbitos de poder, venganza o simplemente el mero placer de cometer un daño.

A veces acontece también que, diciendo lo que no es, el hombre crea y desarrolla un quimérico e ilusorio mundo en el que -en diversas ocasiones- le gusta vivir. Así, por ejemplo, proliferan muchos (sobre todo en posiciones de poder) a la que no les gusta -más bien les horroriza- decir ni que les digan la verdad. Por ello, han establecido una serie o cerco de sanciones, reprobaciones y penalizaciones explícitas que limitan y "exorcizan"la mendacidad.

Ya Platón (428/27-348/47 a. C), en su diálogo Hipias menor (388-385 a. C) señalaba que los mentirosos no eran sino personas "astutas, capaces, inteligentes, conocedoras del engaño y hábiles" ${ }^{\prime \prime 30}$.

No obstante, como bien apunta Sócrates (470/69-399 a. C) en dicho diálogo, "no es mejor el veraz que el mentiroso"131, pues -dirá San Agustín- también se puede decir la verdad para engañar ${ }^{132}$.

Por todo ello, la mentira es siempre y en todo momento algo censurable, tedioso, puesto que supone un pecado que no conduce más que al deshonor, a traicionar la libertad de sí mismo, a violar la libertad y el derecho de la otra persona. Ésta constituye en sí "sólo un pecado venial (que) sin embargo llega a ser mortal cuando lesiona gravemente las virtudes de la justicia y la caridad"133.

Así, el mentir se transforma en "un pecado muy grave", pecado de orgullo y pecado contra el Espíritu, pecado que nos separa de Dios y nos "enfrenta" a Él. Por ello, "este mal grave e impío"134 deberá ser evitado en todo momento y circunstancia.

Por otro lado, dicha falacia constituye en sí misma un concepto unívoco y unísono, no así aquél que la "produce": el mentiroso. Siguiendo la teoría

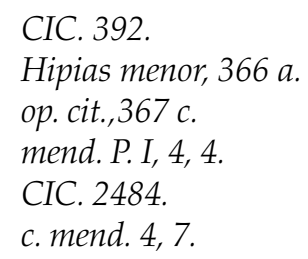


socrática, manifestada en el diálogo platónico citado anteriormente, resulta prácticamente imposible el poder distinguir a aquél del veraz, puesto que ambas cosas (decir y ocultar la verdad) es capaz de realizarlo el mismo sujeto ${ }^{135}$.

Por tanto, esta cuestión representa un "grave dilema", ya que de esta forma estamos afirmando que quien hace un bien, igualmente es capaz de hacer un mal.

Como consecuencia, la mentira no sólo poseerá una dimensión moral, sino -ante todo- una teológica, jurídica, política e incluso lógica.

Pero, igualmente hemos de tener en cuenta que, en ésta misma se puede establecer una especie de "escala moral", es decir,"mentiras más graves o más leves". Recordemos que el mismo San Agustín nos ofreció ya un amplio abanico de tipologías. Así, y teniendo en cuenta dicho abanico, no será lo mismo"mentir en materia de religión" ("es la mentira capital") ${ }^{136}$ que"echar un embuste"-sin deseo alguno de injuriar o calumniar- por "intentar agradar a los hombres, haciendo más agradable la conversación ${ }^{\prime \prime 137}$.

Del mismo modo, y como ya también apuntamos, tampoco las"bromas"-desde el punto de vista agustiniano- deberán ser consideradas como "mentiras", pues "el que las hace no tiene intención de engañar, aunque diga cosas que no son verdaderas"138.

De esta forma, siempre hemos de considerar que no toda aquella persona quien transmita algo falso, sea irremediablemente una mentirosa o esté mintiendo, pues sólo aquél que -expresando algo muy distinto de lo que tiene en su mente- intenta dañar, injuriar o perjudicar a su semejante puede ser considerado como el verdadero"mentiroso".

Es aquí donde radica la causa o el motivo principal del "pecado mortal", pues el triunfo de Satanás es la discordia entre los mismos cristianos ${ }^{139}$. En efecto, la mayor parte de los males del género humano no proceden más que de sospechas falsas ${ }^{140}$.

Toda mentira traiciona, conspira y atenta contra el único bien más preciado que el hombre posee: la libertad, ya que "Dios solo ha concedido esta facultad al hombre entre todos los animales mortales"141.

Así, el mentiroso trasgrede su libre albedrío ya que el objeto de su voluntad libre siempre ha de ser el bien, algo que no acontece en todo momento. Es por todo ello, por lo que -de la misma manera- arrasa la libertad ajena, hacia la cual va dirigida dicha" patraña".

El hombre, nuevamente, se encuentra inmerso en un dualismo vital: hacer el bien (verdad) o elegir el mal (mentira). No obstante, sería éste una especie de "dualismo maniqueo" contra el que Agustín siempre luchó. Por lo tanto, se ha

135 Hipias menor, 369 b.

136 mend. P. II, 14, 25.

137 mend. P. II, 11, 18.

138 mend. P. II, $2,2$.

139 s. $210,12$.

140 s. $306,8-9$.

141 adul. conjung. I, 16, 17. 
de subrayar nuevamente que la libertad, el libre albedrío humano, siempre está orientado y dirigido hacia el bien:

Cuando Dios castiga al que pecó, ¿no te parece que le habla así: "Por qué no has usado la voluntad libre que te di para lo que te la di, esto es, para obrar bien?". ${ }^{142}$

Sin embargo, desgraciadamente, el hombre elige -algunas veces- ser de "color negro" en vez de iluminar con su"buena voluntad", pues:

Observa al pintor. Tiene delante varios colores, y sabe dónde ha de ir cada uno. El pecador quiso ser color negro: ¿tal vez por eso no sabe el artista dónde está su lugar? ${ }^{143}$

Por todo ello, realicemos -al igual que al comienzo de toda la creación, pues "todo era bueno al principio"- el bien, para que así "vean nuestras (vuestras) buenas obras y den gloria a nuestro (vuestro) Padre que está en el cielo". ${ }^{144}$

\section{A MODO DE CONCLUSIÓN}

Mentir no es ocultar la verdad cuando se calla, sino decir lo que es falso cuando se habla ${ }^{145}$

Así, con este juego de palabras agustiniano, podríamos resumir la práctica totalidad del presente trabajo investigativo.

Ha sido siempre la mentira -como ya hemos señalado- una perenne constante en la vida de todo ser humano, aunque si bien siendo empleada con distintas y diversas finalidades: un mero uso defensivo o placentero.

Sin embargo, la cuestión adquiere actualmente un cierto matiz "preocupante", puesto que nunca se ha recurrido tanto a dicha mentira como en nuestros días. Por todo ello, se hará necesario el plantearse la posible y probable dimensión moral que ésta comporta, amén de otras como serían la política o incluso la jurídica.

Y es justamente en la primera dimensión mencionada donde irrumpe con fuerza la figura de Agustín de Hipona, uno de los Padres latinos con mayor y decisiva influencia en el seno de la Iglesia católica.

Su postura es clara y contundente, no dejando lugar a dudas, pues "Es un mal grave e impío que debe ser evitado"146, es decir, toda mendacidad constituye un embarazoso mal moral que -incluso- llega a matar el alma y, por ende, perder la vida eterna.

142 lib. arb. II, 1, 3.

143 s. 125,5 .

144 Mt. 5, 16

145 c. mend. 10, 23.

146 c. mend. $4,7$. 
También para el maestro de Tagaste, se hace necesario una reflexión"seria y rigurosa" sobre dicho asunto, sobre todo ante el desafío priscilianista.

"No se puede mentir en materia de religión"147, algo que dichos "sectarios" ni entienden ni defienden. Ellos tan sólo intentan justificar toda mentira basándose -como ya hemos tenido oportunidad de subrayar- en ciertos pasajes de las Sagradas Escrituras: Génesis 18, 15 o Génesis 27, 19, entre otros.

De la misma manera, San Agustín tampoco puede permitir que estos "heréticos" inciten a los fieles católicos a imitarlos, pues -como bien advierte- "los hijos de la Jerusalén celestial, que son hijos de la verdad, no deben mentir"148.

Ante ello, el "gramático reconocido"149 responde con su tratado Contra la mentira (obra sustentada y complementada por otra que ya compuso antes de ser obispo de Hipona: La mentira).

En ésta manifiesta que aquellos posibles engaños reflejados en la Biblia no son tales, puesto que guardan un significado oculto, alegórico que deberá ser desentrañado.

Por otro lado, existen distintos tipos de mentiras que el obispo africano analiza y clasifica, llegando a la firme conclusión de que todas -sin excepción alguna- deberán ser evitadas y rehusadas.

De esta forma, aconseja al cristiano seguir el precepto que el Señor manifiesta en el Evangelio:

Sea vuestro lenguaje: Sí, sí, no, no... ${ }^{150}$, pues de lo contrario desobedecerá lo mandado en el Decálogo: No dirás falso testimonio ${ }^{151}$.

Así, el hombre no puede ni debe perder la salvación de su alma por mentir ${ }^{152}$, ya que ésta se ha de anteponer no sólo a la vida del prójimo, sino incluso a la nuestra ${ }^{153}$.

Sin embargo, y a pesar de todas estas advertencias agustinianas, podemos apreciar que las mentiras "por desgracia, abundan en la vida"154.

\section{6. “CALLA LA VOZ, GRITA EL CORAZÓN"155: UNA ORACIÓN AGUSTINIANA}

Finalizamos el presente artículo, ilustrándolo con la siguiente oración agustiniana extraída de su obra Confesiones, obra que"constituye un modelo único en la literatura occidental, y no sólo occidental":

\footnotetext{
mend. P. I, 10, 17.

c. mend. 16,33 .

Cresc. I, 2, 3.

Mt. 5, 37.

Éx. 20, 16.

Sab. 1, 11.

mend. P. I, 6, 9.

c. mend. 21, 41.

5 conf. $X, 2,2$.
} 
Dios y Señor mío: está atento a mi corazón y escuche tu misericordia mi deseo, porque no sólo me abrasa en orden a mí, sino también en orden a servir a la caridad fraterna; y que así es, lo ves tú en mi corazón.

Que yo te sacrifique la servidumbre de mi inteligencia y de mi lengua; mas dame qué te ofrezca, porque soy pobre y necesitado y tú rico para todos los que te invocan, y que seguro tienes cuidado de nosotros.

Circuncida mis labios interiores y exteriores de toda temeridad y de toda mentira. Tus Escrituras sean mis castas delicias: ni yo me engañe en ellas ni con ellas engañe a otros.

Atiende, Señor, y ten compasión; Señor, Dios mío, luz de los ciegos y fortaleza de los débiles y luego luz de los que ven y fortaleza de los fuertes, atiende a mi alma, que clama de lo profundo, y óyela. Porque si no estuvieren aun en lo profundo tus oídos, ¿adónde iríamos, adónde clamaríamos?

(Conf. XI, 2, 3). 